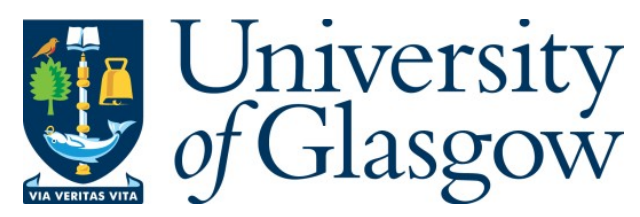

Grove, L. (2015) Charlie Hebdo is nothing new. Jewish Quarterly, 62(1), pp. 4-5.

There may be differences between this version and the published version. You are advised to consult the publisher's version if you wish to cite from it.

http://eprints.gla.ac.uk/122999/

Deposited on: 23 August 2016

Enlighten - Research publications by members of the University of Glasgow http://eprints.gla.ac.uk 


\section{Charlie Hebdo is Nothing New}

\section{Laurence Grove}
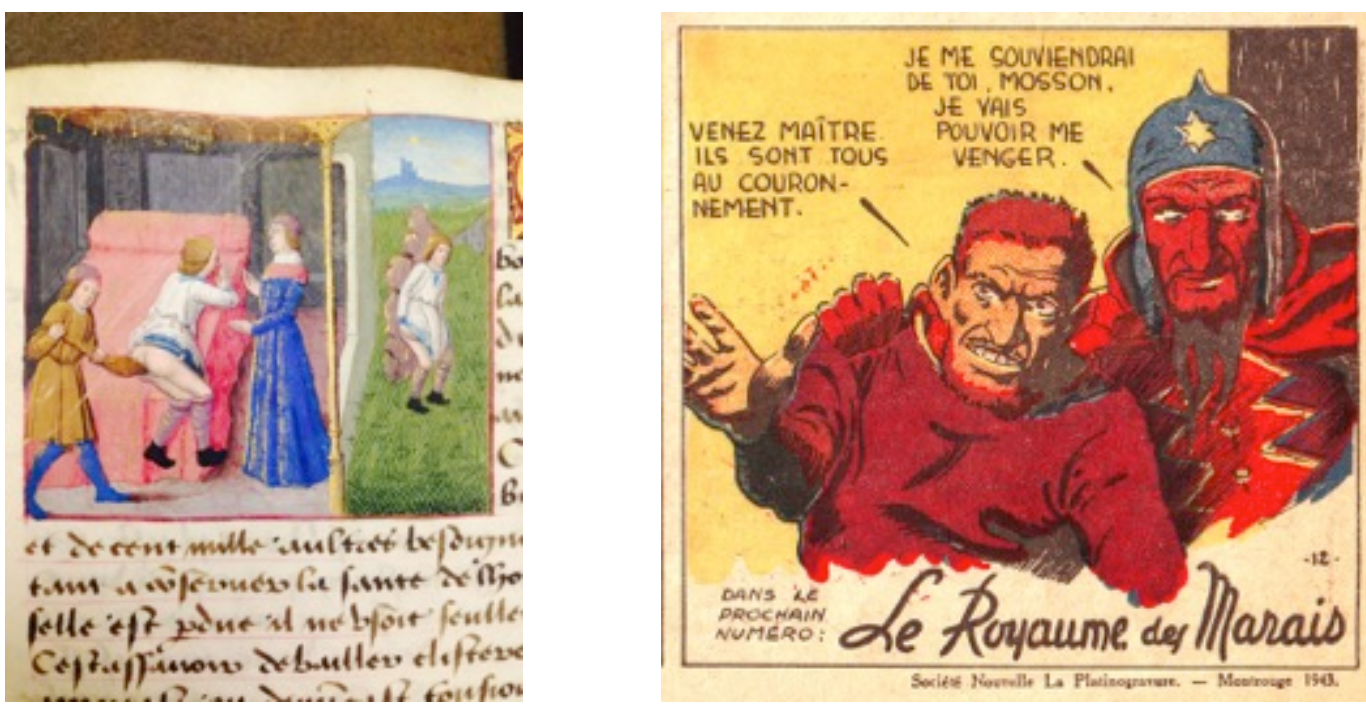

Since last week's tragic events in Paris, Charlie Hebdo is undoubtedly the planet's best-known journal of satirical cartooning, as well as now being the one with by far the highest sales. Yet its trademark features—scatology, vivid sexual humour, and the breaking of taboos, above with respect to, but showing no respect for, religious beliefs-are nothing new.

If we go back to the first collection of French tales, the Cent Nouvelles Nouvelles or One Hundred New Stories of around 1462, we find that the follies of all society are ridiculed, but prominent are those of the priesthood and the nunneries. In the twenty-first tale, for instance, the ailing abbess finds the cure for her deadly malaise to be copulation, but in order for no shame to be felt the selfless sisters volunteer that they too should partake of the medication, which is duly administered by local monks, priests and clerics. The illustration, both in the presentation manuscript and in the printed version of 1486, entices us in with the alluring ladies in a two-frame comic composition, although this one is far from the raunchiest, with other vignettes showing three-in-bed shuffles, bare bottoms and worse, and objects going where they would not normally go.

And that is just the start. In the wake of the sixteenth-century wars of religion printed broadsheets and the best-selling picture books would use the caricatural image 
to mock the powers-that-be, although it was in the nineteenth century that it became an industrial art. The development of the lithograph coupled with mechanical presses that allowed for large-scale distribution meant that the satire of Philipon, Daumier, Doré and others could reach a mass audience eager to snap up the new illustrated magazines. As with Charlie Hebdo the line between cutting social satire and provocative racism could be thin and debateable. Caran d'Ache's Carnet de chèques of 1892, a set of cartoons in the form of a chequebook, satirises the Panama Canal Scandal, but does so by showing anti-Semitic caricatures eagerly making business profit out of the political situation.

As illustrated journals for adults evolved towards the bande dessinée or comic strip, nowadays dubbed as France's Ninth Art, visual caricature would hold strong, even in publications ostensibly aimed at children. An example that escaped the history books for many years was the collaborationist wartime Téméraire, wherein exaggerated physiognomy made it clear that the Jews were the baddies. And although many of those who were believed to have supported the Nazis in other cultural domains-Sacha Guitry for cinema, Paul de Man for philosophy-were publically taken to task, those who drew cartoons went on to long and healthy careers, in some cases switching over seamlessly to the Communists!

Post 1968, comics were not left out of the social revolution and went openly adult. L'Echo des Savanes took authors from René Goscinny's Pilote (of Astérix fame) and had them throw sexy and rude metaphorical bricks at the establishment, whereas in the mid-1970s Ah! Nana launched cutting female-run and feminist satire, only to fall foul of the censor-ostensibly for its number on incest-and fold nine issues later. The precursor to Charlie Hebdo, Hara-Kiri Hebdo, was famously banned for mocking De Gaulle's death on the cover of a 1970 issue. And then came Charlie...

Why then does France seem to specialise in cartoon satire? Perhaps that is as hard to answer as why is Germany good at football, or why are the Swiss excellent chocolate makers? Well, part of the answer must be because they always have been. When the image first came to be mass-produced in Europe via the printing presses of the fifteenth and sixteenth centuries, France was at the geographic crossroads, meaning that Lyon and Paris became centres for the new technology. This technology took us from the visual age of the stained-glass story-telling of the great cathedrals to a mixed-medium text and image distribution, before text came to dominate the 
printing trade and we saw the wordy novels of the nineteenth century. I would say we are now back in a hybrid world, as visual technology is all around us, but text is what we learn at school. And again France is at the forefront of the new technologies, having invented the cinema (the Lumière Brothers), and almost invented the internet (via the Minitel system). The shift to a completely visual culture is not complete, thus hybrid text/image forms, such as cartooning, thrive. The image draws us in, but the text pinpoints, or anchors, the specifics of sense. For the theory behind this, see (or read) another Frenchman, Roland Barthes.

In addition social upheaval has always helped counter-culture flourish, and here France has had its fair share: the wars of the religion at the time of the Renaissance, the Revolution prior to the Industrial Revolution, and then the Nazi occupation are three examples ample for any country's history. Pitch counter-culture against a strongly centralised state mechanism—for which France has excelled since the days of Napoleon-and the result is not just strikes and demonstrations, but also satire that strongly says merde.

Not just says merde, but shows us it hot and steaming. Although in England Private Eye is famously founded and run by members of the Oxbridge social elite (although often misfits), in general the establishment is slow to accept popular visual culture. My feeling is that it would be difficult to persuade a funding body such as the AHRC or the BA to support a National Comics Academy, even if the world's media are buzzing with Charlie Hebdo. Visual satire has to operate through a healthy system of going against the grain, which, history tells us, like petits fours, is often best served in France.

So where are we now? To return to our opening example, the medieval One Hundred New Stories, it is interesting to note that throughout the early part of the twentieth century all scholarly editions omitted the (admittedly rude) images, even though these are central to the tone and reception of the stories. Now in the twentyfirst century images are not omitted, au contraire, and in addition it is they that have the power to offend and shock on a grand scale. Such is the case for the front cover of Charlie Hebdo which shows the Prophet Mohammed telling us 'all is forgiven', but it can only have the effect it has because an equal part of our new visual age is the looping sound-bite videos by which TV and the web send Charlie Hebdo, and the terrorists, around the world. 
Laurence Grove is Professor of French and Text/Image Studies and Director of the Stirling Maxwell Centre for the Study of Text/Image Cultures at the University of Glasgow. His research focuses on historical aspects of text/image forms, and in particular bande dessinée (French comics). He is President of the International Bande Dessinée Society ('www.arts.gla.ac.uk/ibds'). Laurence Grove has authored (in full or jointly) nine books, including Comics in French (Oxford, Berghahn), and approximately fifty chapters or articles. He is currently preparing an exhibition on the World's First Comic. 